\title{
Chapter 3 \\ Impacts of the Fukushima Nuclear Accident on Fishery Products and Fishing Industry
}

\author{
Takami Morita, Daisuke Ambe, Shizuho Miki, Hideki Kaeriyama, \\ and Yuya Shigenobu
}

\begin{abstract}
On March 11, 2011, a massive earthquake and the resultant gigantic tsunami struck the Tohoku area of Japan (the Great East Japan Earthquake) and damaged many fishing boats and fishing ports. The earthquake and the subsequent tsunami also seriously caused the damage to Fukushima Daiichi Nuclear Power Plant (FNPP). Consequently, large amounts of radioactive cesium (Cs) were released into the atmosphere and ocean and subsequently polluted fishery products of Fukushima and adjacent prefectures. The Fukushima Prefectural Federation of Fisheries Cooperative Association (Fukushima FCA) has voluntarily stopped the fishing operations off Fukushima Prefecture since March 2011 due to the influence by the FNPP accident. The concentration of radioactive Cs in seawater rapidly decreased by ocean processes, and accordingly the concentration in fishery products did reduce. From April to June 2011, the proportion of inspected specimens off Fukushima exceeding the Japanese regulatory limit was $57.1 \%$, but it decreased and continued to be $0 \%$ after April 2015. In addition, most of fishing industries in Fukushima Prefecture have been already restored from the damage by the earthquake and its aftermath. The Fukushima FCA started the trial fishing operation from June 2012.
\end{abstract}

Keywords Monitoring research $\cdot$ Fishery products $\cdot$ Radioactive cesium · Fukushima prefecture $\cdot$ Trial fishing operation

\footnotetext{
T. Morita $(\bowtie) \cdot$ S. Miki $\cdot$ H. Kaeriyama $\cdot$ Y. Shigenobu Radioecology Group, Research Center for Fisheries Oceanography and Marine Ecosystem, National Research Institute of Fisheries Science, Fisheries Research Agency,

Yokohama, Japan

e-mail: takam@affrc.go.jp

D. Ambe

Fisheries Environment Group, Research Center for Fisheries Oceanography and Marine Ecosystem, National Research Institute of Fisheries Science, Fisheries Research Agency, Yokohama, Japan
} 


\subsection{Introduction}

On March 11, 2011, a massive earthquake (moment magnitude 9.0) and a resultant gigantic tsunami struck the Tohoku area of Japan (the Great East Japan Earthquake). According to the report by the Fisheries Agency of Japan (FAJ), the aftermath of the earthquake damaged around 29,000 fishing boats and 319 fishing ports, which were approximately $10 \%$ of each total number in Japan [1]. Until January 2018, 18,614 fishing boats and all fishing ports have regained the function. The fishing industries in the tsunami-damaged areas excluding Fukushima Prefecture have been steadily recovering from the disaster. On the other side, the fishing industry in Fukushima has another unavoidable problem.

The earthquake and tsunami caused serious damage to FNPP. Consequentially, FNPP released a significant quantity of radionuclides into the atmosphere, and the fall out peaked around March 15, 2011 [2-4]. Although various radionuclides were released [5], the major radionuclides were radioactive iodine (I), ${ }^{131} \mathrm{I}$ (physical halflife; 8.02 days), and two kinds of radioactive cesium (Cs), ${ }^{134} \mathrm{Cs}$ (2.06 years) and ${ }^{137} \mathrm{Cs}$ (30.1 years). Radioactivity of ${ }^{134} \mathrm{Cs}$ and ${ }^{137} \mathrm{Cs}$ released was approximately equal [2]. The total quantity of ${ }^{131} \mathrm{I}$ and ${ }^{137} \mathrm{Cs}$ into the atmosphere between March 12, 2011, and May 1, 2011, was estimated to be approximately $200 \mathrm{PBq}$ and $13 \mathrm{PBq}$, respectively [6]. Furthermore, the amount of ${ }^{137} \mathrm{Cs}$ deposited on the ocean surface from the atmosphere was estimated as 7.6 PBq [6] and 12-15 PBq [7], and meaning that most of ${ }^{137} \mathrm{Cs}$ released to the atmosphere was introduced into the ocean. In addition, extremely contaminated cooling water, which interacted with the ruptured nuclear fuel rods, was leaked from a cracked sidewall near the intake channel of Unit 2 reactor during April 1-6 in 2011. Nuclear Emergency Response Headquarters of Japan (NERH) estimated that the contaminated water contained 4.7 PBq of radionuclides including ${ }^{131} \mathrm{I},{ }^{134} \mathrm{Cs}$, and ${ }^{137} \mathrm{Cs}$ [8]. Another report indicated that the direct release to the ocean had already been going on March 26, 2011, and estimated that the total amount of ${ }^{137} \mathrm{Cs}$ directly released was $3.5 \pm 0.7 \mathrm{PBq}$ from March 26, 2011 to the end of May 2011 [9].

The Fukushima FCA did not fully grasp the radioactive pollution of fishery products off Fukushima by the large amounts of radionuclides from FNPP in March 2011. Additionally, not all fishing boats and fishing ports in Fukushima Prefecture were damaged by the aftermath of the earthquake. However, the Fukushima FCA decided to voluntarily stop the fishing operations off Fukushima for the food safety on March 15, 2011 [10]. Consequently, this voluntary stop of the fishing operations has been continuing from March 2011 to the present (August, 2019), by the monthly update. In such a situation, the Fukushima FCA started the trial fishing operation from June 2012 off Fukushima [11].

In this chapter, we introduce the radioactive pollution in fishery products and the state of the fisheries industry in Fukushima Prefecture. 


\subsection{Radioactive Pollution of Fishery Products}

Marine organisms generally incorporate ${ }^{134} \mathrm{Cs}$ and ${ }^{137} \mathrm{Cs}$ (radioactive Cs) both by uptake from seawater or by food ingestion. Therefore, radioactive Cs concentration in marine organisms depends strongly on that in surrounding seawater, which effects the concentration in the food organisms. The extremely highly contaminated water leaked directly into oceans around March to April in 2011 [8, 9]. However, as radioactive Cs concentration in seawater rapidly decreased by ocean processes [12], that in the pelagic fishes, invertebrates and seaweeds accordingly decreased [13-16]. Although it is pointed out that the decrease rate of radioactive Cs concentration in demersal fishes is slow [12], that in demersal fishes has been steadily decreasing over time in the monitoring research [17]. Figure 3.1 shows radioactive Cs concentration in rockfish (Sebastes cheni), one of demersal fishes, in both north and south of FNPP. The maximum concentration, $3200 \mathrm{~Bq} / \mathrm{kg}$-wet, was detected in the south area on July 6, 2011 [17]. Radioactive Cs concentration in the south area was higher than that in the north area, because extremely contaminated water mainly flowed to the south area $[12,18]$. The traces of flow were found on the distribution map of radioactive Cs concentration in the sediment off Fukushima [19]. A previous research described that radionuclide bioavailability from contaminated sediment is typically low with the transfer factor [20] because of strong interaction of Cs mineral with clay minerals [21]. But, the slow decrease of radioactive Cs in demersal fishes was presumed as the result from continuing contamination of their food

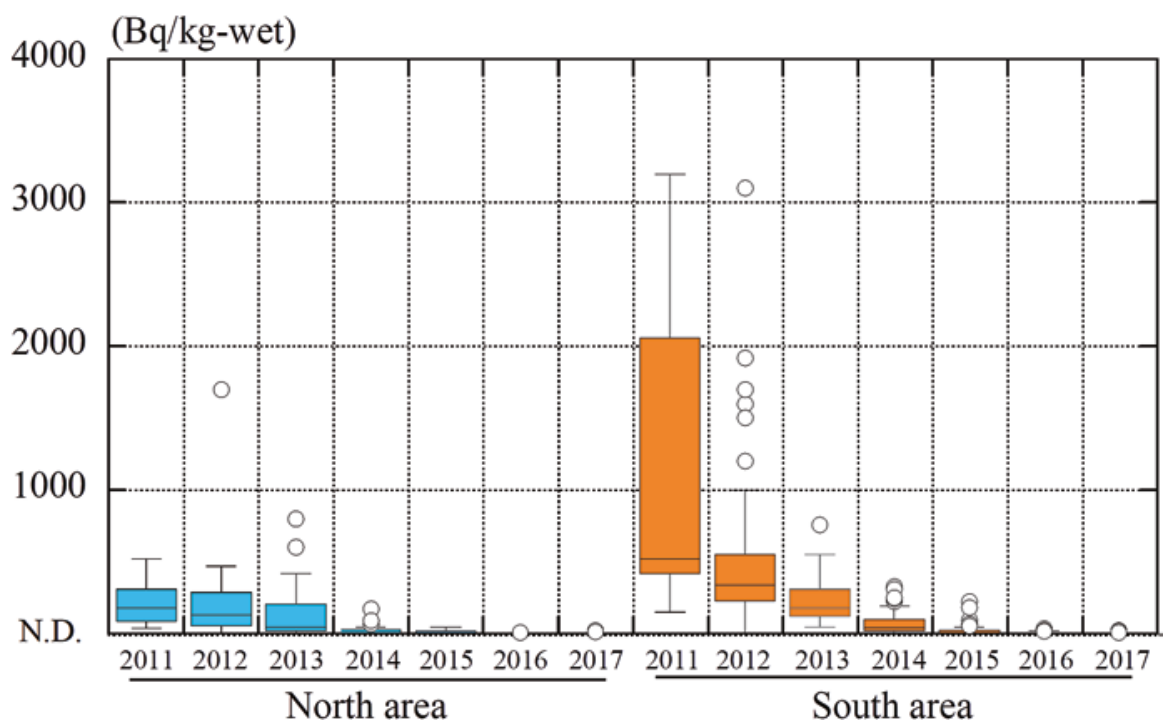

Fig. 3.1 Concentration of radioactive cesium $\left({ }^{134} \mathrm{Cs}+{ }^{137} \mathrm{Cs}\right.$ ) in rockfish (Sebastes cheni) collected in the north area (blue) and the south area (orange) from FNPP. N.D. shows not detected (detection limit < about 5.0 Bq/kg-wet for each radioactive Cs). (Data were cited from FAJ [17]) 
source (benthic infauna) from sediment [13, 15, 16, 22-25]. In fact, some studies after the FNPP accident indicated the presence of organically bound radioactive Cs, which can be bioavailable [26, 27].

The change of main year-class composing a population was a cause for decrease of radioactive Cs concentrations in fishery products including demersal fishes. A year-class-related differences of radioactive Cs concentration in some fish species, Pacific cod (Gadus microcephalus) and Japanese flounder (Paralichthys olivaceus), have been reported [28, 29]. The 2010 year-class and older classes had relatively higher concentrations of radioactive Cs than 2011 year-class and younger classes. The finding that year-classes born after the FNPP accident had lower concentration indicates that they incorporated only a small amount of radioactive Cs from the benthic food web.

High radioactive Cs concentration, 25,800 Bq/kg-wet, was detected in the specimen prepared from two greenlings (Hexagrammos otakii). The fish samples were caught close to Ota River approximately $20 \mathrm{~km}$ from FNPP in August 2012. Although these two outlier samples were thought to have migrated from the FNNP port, the probability of such outlier samples being found off Fukushima was exceedingly low [30]. Indeed, some fishes caught within the FNPP port remained highly contaminated, and the maximum concentration, 720,000 Bq/kg-wet, was detected in greenling collected on February 21, 2013. Therefore, TEPCO has set nets and prevented fishes from leaving the port. They also caught fishes in the FNPP port using fishing nets, and the total number of fishes was about 5000 samples from 2012 to 2018 [16, 30-32].

\subsection{Monitoring Research in Fishery Products}

The Japanese government has conducted the monitoring research of radionuclides ${ }^{(131} \mathrm{I},{ }^{134} \mathrm{Cs}$ and ${ }^{137} \mathrm{Cs}$ ) in fishery products for food safety since March 2011 (Fig. 3.2) [17]. TEPCO also carried out the monitoring research of fishery products collected in the 20-km zone from FNPP and in the FNPP port [33]. By the end of January 2018, over 50,000 fishery products off Fukushima have been inspected. Many independent research articles about fishery products have been published using these monitoring data and showed that radioactive Cs concentration in fishery products decreased [13-16, 22, 23, 32, 34]. The monitoring research by the Japanese government showed $57.1 \%$ of inspected fishery products off Fukushima were over the Japanese regulatory limit (100 Bq/kg-wet for radioactive Cs) in the period immediately following the accident (April-June 2011), but the ratio gradually reduced and continued to be 0\% since April 2015 (Fig. 3.2). The statistical methods also demonstrated that the probability of occurrence of fishery products exceeding the Japanese regulatory limit was already extremely low in 2015 [35].

The Ministry of Health, Labour and Welfare (MHLW) of Japan also conducted the inspection of radioactive $\mathrm{Cs}$ in the food distributed on the market (Table 3.1) [36]. There were just two specimens over the Japanese regulatory limit (provisional 


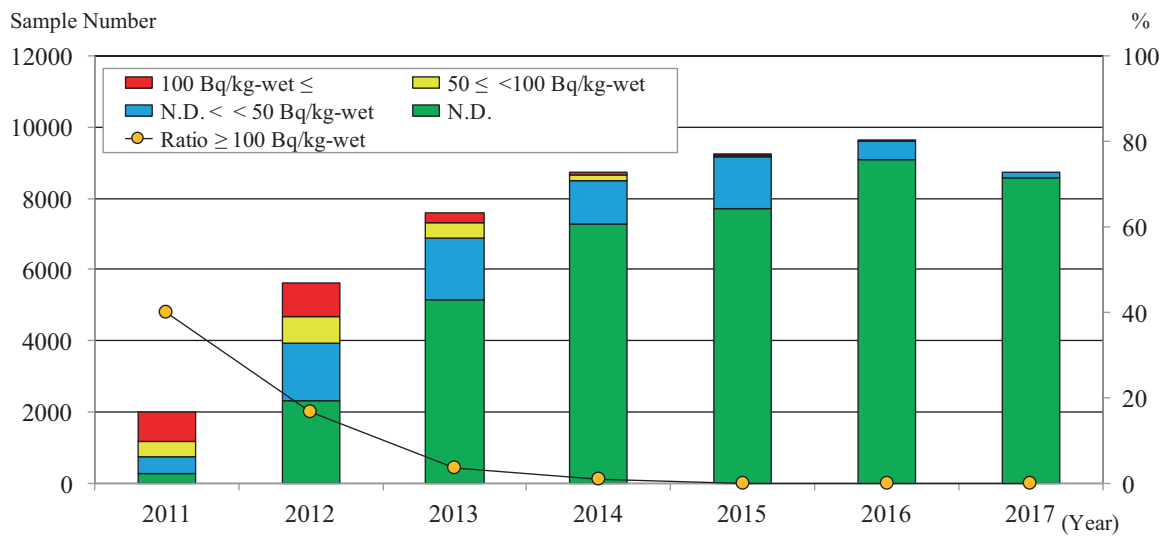

Fig. 3.2 Result of the monitoring research for radioactive cesium $\left({ }^{134} \mathrm{Cs}+{ }^{137} \mathrm{Cs}\right)$ in fishery products collected off Fukushima. N.D.: not detected (detection limit < about 5.0 Bq/kg-wet for each radioactive Cs). (Data were cited from FAJ [17])

Table 3.1 Number of exceeding the Japanese regulatory limit in the inspection for distribution foods

\begin{tabular}{l|l|l|l|l|l}
\hline Year $^{\mathrm{a}}$ & $\begin{array}{l}\text { Fishery } \\
\text { products }\end{array}$ & $\begin{array}{l}\text { Agricultural } \\
\text { products }\end{array}$ & $\begin{array}{l}\text { Meats (including wild } \\
\text { animals })\end{array}$ & $\begin{array}{l}\text { Egg/dairy } \\
\text { products }\end{array}$ & Others \\
\hline 2011 & $2(0)^{\mathrm{b}}$ & $57(13)^{\mathrm{b}}$ & $561(91)^{\mathrm{b}}$ & $0(0)^{\mathrm{b}}$ & $\begin{array}{l}91 \\
(18)^{\mathrm{b}}\end{array}$ \\
\hline 2012 & 2 & 6 & 1 & 0 & 11 \\
\hline 2013 & 0 & 8 & 0 & 0 & 2 \\
\hline 2014 & 0 & 8 & 0 & 0 & 2 \\
\hline 2015 & 0 & 8 & 1 & 0 & 3 \\
\hline 2016 & 0 & 9 & 0 & 0 & 2 \\
\hline $2017^{\mathrm{c}}$ & 0 & 9 & 0 & 0 & 4 \\
\hline
\end{tabular}

Data were cited from MHLW [36]

${ }^{a}$ Fiscal year from April to March in the next year

${ }^{b}$ Numbers in parentheses are numbers exceeding provisional regulation limit (500 Bq/kg-wet)

'April in 2017 to January in 2018

regulation limit in 2011) in fishery products since 2011. The FAJ succeeded in preventing the contaminated fishery products from being distributed. They also properly stopped the distribution of contaminated feed for aquaculture. Therefore, none of the aquaculture fishery products exceeded the Japanese regulatory limit (provisional regulation limit in 2011) not only in distribution food inspection but also in the monitoring research.

Radioactive strontium $\left({ }^{89} \mathrm{Sr}\right.$ and $\left.{ }^{90} \mathrm{Sr}\right)$ is one of the nuclear fission products as well as ${ }^{137} \mathrm{Cs}$. Therefore, many people have been concerned about pollution of fishery products by radioactive Sr since the FNPP accident happened. Strontium-90 had been detected in fishery products before the FNPP accident [37]. The main source 
of ${ }^{90} \mathrm{Sr}$ in the North Pacific Ocean off Japan was the global and close-in radioactive fallout after the atmospheric nuclear bomb tests and the Chernobyl NPP accident $[38,39]$. The average concentration of ${ }^{90} \mathrm{Sr}$ in marine fishes of the North Pacific Ocean off Japan was $0.025 \pm 0.021 \mathrm{~Bq} / \mathrm{kg}$-wet in the past two decades before the FNPP accident [40].

Owing to the lower volatility than $\mathrm{Cs}$, the amount of ${ }^{90} \mathrm{Sr}$ released into the atmosphere from the FNPP accident is estimated to be about $0.14 \mathrm{PBq}$ [41], which is two orders of magnitude smaller than that of radioactive ${ }^{137} \mathrm{Cs}, 20 \mathrm{PBq}[6,7]$. An extremely contaminated cooling water was leaked from a cracked sidewall near the intake channel of Unit 2 from late March to early April 2011 [8, 9]. The contaminated water including high concentration of radioactive $\mathrm{Sr}$ and Cs directly flowed into the ocean. Based on the initial ${ }^{137} \mathrm{Cs} /{ }^{90} \mathrm{Sr}$ activity ratio released from the FNPP accident and 3.5 PBq of ${ }^{137} \mathrm{Cs}$ directly was released into the ocean, the amount of ${ }^{90} \mathrm{Sr}$ in the contaminated water was estimated to be approximately $0.04 \mathrm{PBq}[9,41]$. The International Atomic Energy Agency (IAEA) summarized the concentration factor of many elements for various aquatic organisms [42]. The value of concentration factor for $\mathrm{Sr}$ in marine fishes was 3 and lower than that for Cs, 100. In addition, ${ }^{90} \mathrm{Sr}$ in seawater was immediately diluted to the background level [41]. Therefore,

${ }^{90} \mathrm{Sr}$ concentration in fishery products was notably lower than that of ${ }^{137} \mathrm{Cs}$ even off Fukushima, and ${ }^{90} \mathrm{Sr}$ derived from the FNPP accident would not be detected in fishery products caught outside off Fukushima [40]. In conclusion, the influence of the FNPP accident by ${ }^{90} \mathrm{Sr}$ pollution on fishery products has been limited to the area off Fukushima though negligible $[40,43]$.

\subsection{Trial Fishing Operations in Fukushima}

The fishery products off Fukushima were polluted by large amounts of radioactive Cs released from FNPP. However, the Japanese and the Fukushima prefectural governments did not revoke the fishing licenses in Fukushima Prefecture, because the Fukushima FCA voluntarily continued to stop the fishing operations off Fukushima for the food safety from March 15, 2011 by the monthly update. In February 2012, the Fukushima FCA established the Fukushima Prefectural Fisheries Reconstruction Committee (Fukushima FRC) with external experts in order to reconstruct the fishery industry and restart the fishing operation off Fukushima [10].

In June 2012, based on the advice of the Fukushima FRC, the Fukushima FCA decided to carry out the trial fishing operation off Fukushima. The trial fishing operation has several limitations: the target species, the fishing methods, the number of days a week for operation, landing ports, the amount of landed fishes, the number of vessels involved in operations and the areas for operations [10]. The areas for the trial fishing operations are shown in Fig. 3.3. At first, the trial fishing operation for bottom trawling was performed only in area 1 . The operation area has been expanded to include area 2 in October 2012, area 3 in February 2013, area 4 in May 2013, area 5 in August 2013, area 6 in December 2013, area 7 in October 


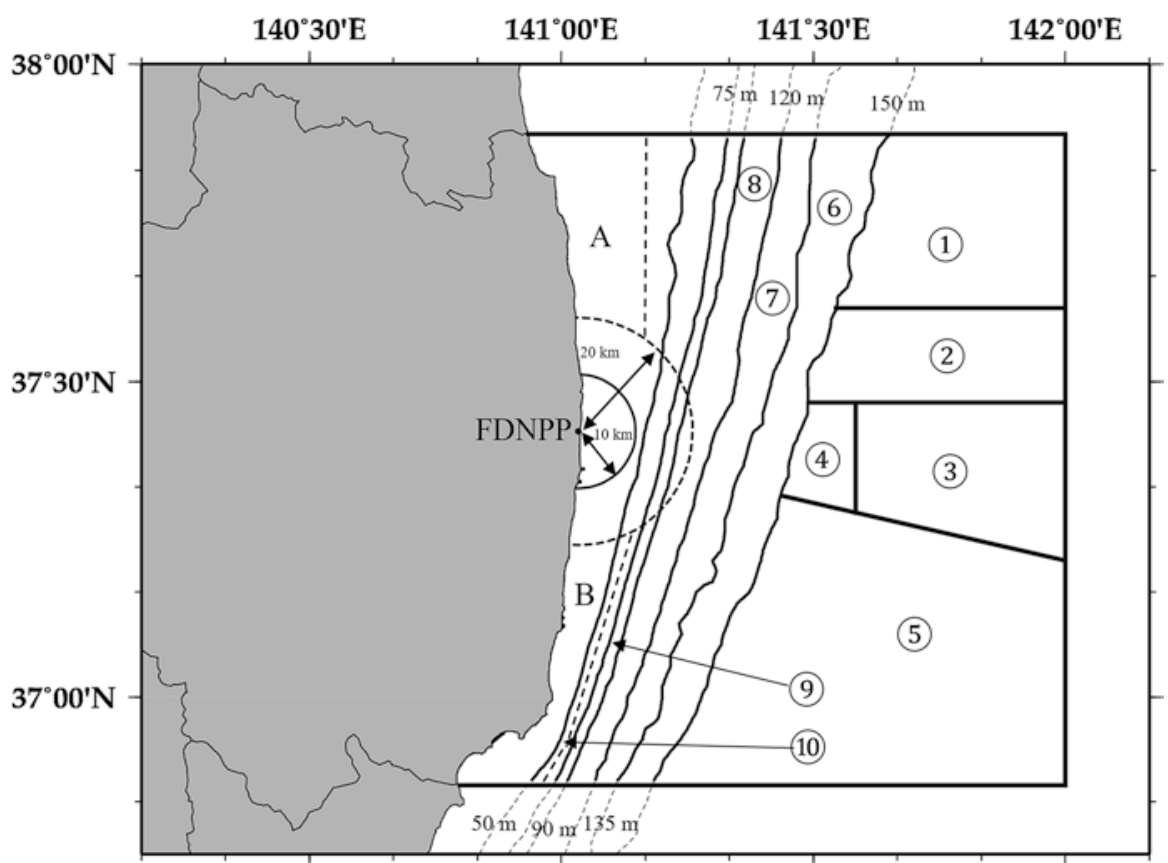

Fig. 3.3 Areas for the trial fishing operation. (Data were cited from Fukushima FCA [11])

2014, area 8 excluding the 20-km zone in October 2015, area 9 in February 2017 and area 10 in October 2017. The trial fishing operations of shipping net for young sand lance (Ammodytes personatus) and piercing net for icefish (Salangichthys ishikawae) were conducted in areas A and B surrounded by the $20-\mathrm{km}$ zone line (dotted lines) and land, respectively (Fig. 3.3). The trial fishing operation of shipping net in areas A and B was allowed in March 2013 and February 2014, respectively. The trial fishing operation of piercing net in areas A and B was done in February 2014. The range of the trial fishing operation did not include the $20-\mathrm{km}$ zone until the end of February 2017. From March 2017, the range of the trial fishing operation covered all the areas excluding the 10-km zone off Fukushima. The reason for excluding the $10-\mathrm{km}$ zone was the presence of the fishes having high concentration of radioactive Cs in the FNPP port. As described above, TEPCO has set the net preventing fishes from coming in and going out the port and also exterminated fishes in the port by fishing nets [33].

The total number of target species for the trial fishing operation gradually increased (Fig. 3.4). First target species were three invertebrate species, two kinds of octopuses (Enteroctopus dofleini and Octopus conispadiceus), and a whelk (Buccinum isaotakii). These species were selected based on the monitoring research result, which showed no detection of radioactive $\mathrm{Cs}$ in these species (detection limit is under about 5.0 Bq/kg-wet for each radioactive $\mathrm{Cs}$ ). The monitoring result was consistent with the previous report that concentration factor of 


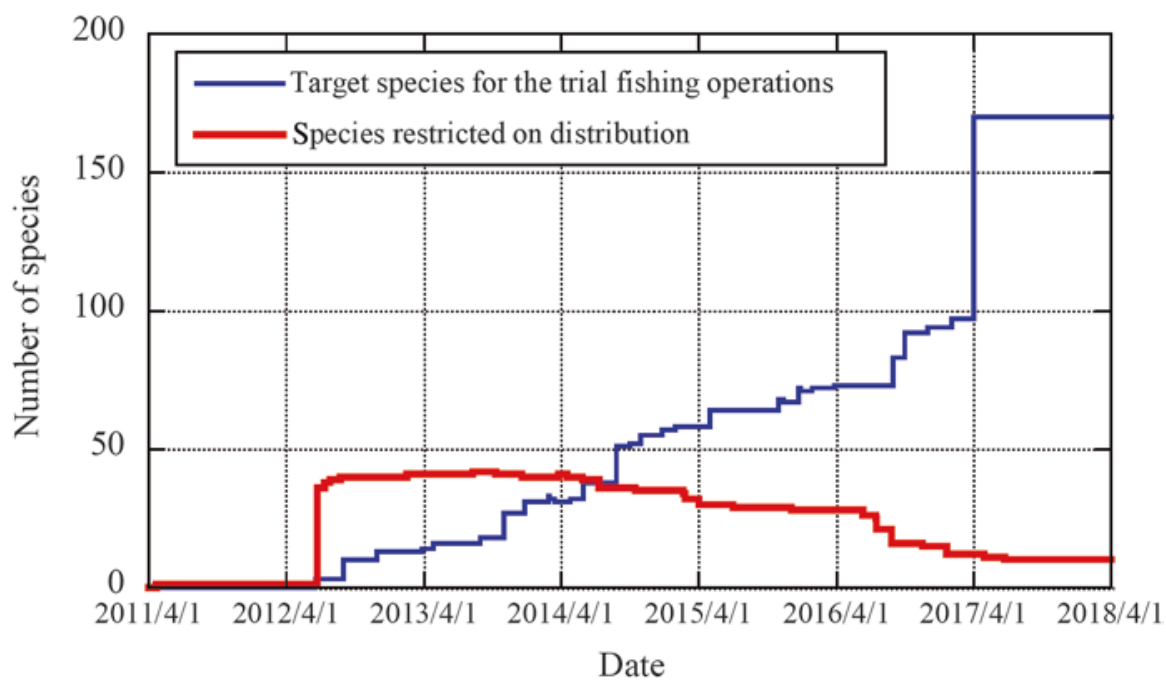

Fig. 3.4 Temporal change of the number of target species for the trial fishing operation (blue line) and the species restricted on the distribution (red line). (Data were cited from FAJ [17] and Fukushima FCA [11])

radioactive Cs in marine mollusc species is lower, up to 9 for cephalopods and 60 for others as compared with marine fish species, up to 100 [42]. In April 2018, the Fukushima FCA recognized all fish species for fishery industry off Fukushima as the target species except for 10 species restricted on the distribution (about 170 species). The ten species were surfperch (Ditrema temminckii), fox jacopever (Sebastes vulpes), Japanese black seabream (Acanthopagrus schlegelii), masu salmon (Oncorhynchus masou), rockfish (Sebastes cheni), Japanese sea bass (Lateolabrax japonicus), starry flounder (Platichthys stellatus), Spotbelly rockfish (Sebastes pachycephalus), marbled rockfish (Sebastiscus marmoratus) and Stimpson's hard clam (Mercenaria stimpsoni). However, radioactive Cs concentration in these species was not necessarily high even in March 2018. The respective concentration for ten species has been below $25 \mathrm{~Bq} / \mathrm{kg}$-wet from October 2017 to March 2018 [17]. The Japanese government had not restricted the fishery products except for young sand lance off Fukushima until launching the trial fishing operation, because the fishing operation off Fukushima was voluntarily stopped by the Fukushima FCA. When the trial fishing operation off Fukushima started in June 2012, 36 species were restricted on the distribution by the government. The numbers of species restricted on the distribution reached the maximum of 42 species in August 2013 and gradually decreased to 10 species in June 2017 (Fig. 3.4). The restriction of the distribution is lifted by the Japanese Government, when the result of monitoring research is stably and sufficiently below the Japanese regulatory limit. However, the criteria for lifting the distribution restriction has not yet been announced. The development of scientific/statistical framework for lifting the distribution restriction will be required in order to promptly restore the livelihoods of local farmers, fishermen, and other food producers [44]. 
Table 3.2 Amount of landing in the trial fishing operations in Fukushima Prefecture and comparison with that before the FNPP accident

\begin{tabular}{l|l|l|l|l|l|l|l}
\hline Year & 2010 & 2012 & 2013 & 2014 & 2015 & 2016 & 2017 \\
\hline Amount of landing (t) & 25,914 & 122 & 406 & 742 & 1512 & 2100 & 3286 \\
\hline Comparison with 2010 (\%) & - & 0.471 & 1.57 & 2.86 & 5.83 & 8.10 & 12.7 \\
\hline
\end{tabular}

Data were provided from the Fukushima FCA

The catch amount of the trial fishing operation has been gradually increasing year by year, but the amount in 2017 was $12.7 \%$ of that before the FNPP accident (Table 3.2). Although most of the fishing boats and the ports in Fukushima Prefecture have already been recovered, the increase of catch amount has been slow. The reason is that the FNPP accident has lost the confidence of consumer and distributor for the safety of fishery products off Fukushima, and additionally most of them could not purchase the Fukushima fishery products due to the reduced distribution amount, so, they switched to other production areas for purchasing fishery products. In order to restore their lost confidence, it is important to continue careful monitoring research and provide scientific information supporting the monitoring research results. We hope the distribution amount off Fukushima will increase in the future.

Acknowledgments We appreciate the staff members of the Fukushima FCA for providing the amount of landing data in the trial fishing operation. We thank all fishery workers in Fukushima Prefecture for cooperating with the monitoring research. We also thank the staff members of Radioecology Group for great help.

\section{References}

1. FAJ (2018a) The great East Japan earthquake's impact on fisheries and future measures. http:// www.jfa.maff.go.jp/attach/pdf/index-47.pdf. Accessed 24 Mar 2018. (in Japanese)

2. Chino M, Nakayama H, Nagai $\mathrm{H}$ et al (2011) Preliminary estimation of release amounts of ${ }^{131} \mathrm{I}$ and ${ }^{137} \mathrm{Cs}$ accidentally discharged from the Fukushima Daiichi Nuclear Power Plant into the atmosphere. J Nucl Sci Technol 48:1129-1134

3. Morino Y, Ohara T, Nishizawa M (2011) Atmospheric behavior, deposition, and budget of radioactive materials from the Fukushima Daiichi Nuclear Power Plant in March 2011. Geophys Res Lett 38:L00G11

4. Masumoto Y, Miyazawa Y, Tsumune D et al (2012) Oceanic dispersion simulations of ${ }^{137} \mathrm{Cs}$ released from the Fukushima Daiichi Nuclear Power Plant. Elements 8:207-212

5. Steinhauser G (2014) Fukushima's forgotten radionuclides: a review of the under- studied radioactive emissions. Environ Sci Technol 48:4649-4663

6. Kobayashi T, Nagai H, Chino M et al (2013) Source term estimation of atmospheric release due to the Fukushima Dai-ichi Nuclear Power Plant accident by atmospheric and oceanic dispersion simulations. J Nucl Sci Technol 50:255-264

7. Aoyama M, Kajino M, Tanaka TY et al $(2016){ }^{134} \mathrm{Cs}$ and ${ }^{137} \mathrm{Cs}$ in the North Pacific Ocean derived from the TEPCO Fukushima Dai-ichi Nuclear Power Plant accident, Japan in March 2011: part two - estimation of ${ }^{134} \mathrm{Cs}$ and ${ }^{137} \mathrm{Cs}$ inventories in the North Pacific Ocean. J Oceanogr 72:67-76 
8. NERH (2011) Report of the Japanese government to the IAEA ministerial conference on nuclear safety. http://www.kantei.go.jp/foreign/kan/topics/201106/iaea_houkokusho_e.html. Accessed 27 Jan 2014

9. Tsumune D, Tsubono T, Aoyama $\mathrm{M}$ et al (2012) Distribution of oceanic ${ }^{137} \mathrm{Cs}$ from the Fukushima Daiichi nuclear power plant simulated numerically by a regional ocean model. J Environ Radioact 111:100-108

10. Yagi $N$ (2016) Impact of the nuclear power plant accident and the start of trial operations in Fukushima fisheries. In: Nakanishi TM, Tanoi T (eds) Agricultural implications of the Fukushima nuclear accident. Springer, Tokyo, pp 217-228

11. Fukushima FCA (2018) The trial fishing operations off Fukushima. http://www.fsgyoren.jfnet.ne.jp/siso/sisotop.html. Accessed Feb 2014. (in Japanese)

12. Aoyama M, Tsumune $\mathrm{D}$, Uematsu $\mathrm{M}$ et al (2012) Temporal variation of ${ }^{134} \mathrm{Cs}$ and ${ }^{137} \mathrm{Cs}$ activities in surface water at stations along the coastline near the Fukushima Dai-ichi Nuclear Power Plant accident site, Japan. Geochem J 46:321-325

13. Buesseler KO (2012) Fishing for answers off Fukushima. Science 338:480-482

14. Iwata K, Tagami K, Uchida S (2013) Ecological half-lives of radiocesium in 16 species in marine biota after the TEPCO's Fukushima Daiichi nuclear power plant accident. Environ Sci Technol 47:7696-7703

15. Wada T, Nemoto Y, Shimamura S et al (2013) Effects of the nuclear disaster on marine products in Fukushima. J Environ Radioact 124:246-254

16. Wada T, Fujita T, Nemoto Y et al (2016) Effects of the nuclear disaster on marine products in Fukushima: an update after five years. J Environ Radioact 164:312-324

17. FAJ (2018b) Results of the monitoring on radioactivity level in fisheries products. http://www. jfa.maff.go.jp/e/inspection/index.html. Accessed 24 Mar 2018

18. Tsumune D, Tsubono T, Aoyama $\mathrm{M}$ et al (2013) One-year, regional-scale simulation of ${ }^{137} \mathrm{Cs}$ radioactivity in the ocean following the Fukushima Dai-ichi Nuclear Power Plant accident. Biogeosciences 10:5601-5617

19. Ambe D, Kaeriyama H, Shigenobu Y et al (2014) Five-minute resolved spatial distribution of radiocesium in sea sediment derived from the Fukushima Dai-Ichi nuclear power plant. J Environ Radioact 138:264-275

20. Fowler SW, Fisher NS (2004) Radionuclides in the biosphere. In: Livingston HD (ed) Marine radioactivity. Elsevier, Amsterdam, pp 167-203

21. Comans RNJ, Hockley D (1992) Kinetics of cesium sorption on illite. Geochim Cosmochim Acta 56:1157-1164

22. Tateda Y, Tsumune D, Tsubono T (2013) Simulation of radioactive cesium transfer in the southern Fukushima coastal biota using a dynamic food chain transfer model. J Environ Radioact 124:1-12

23. Tateda Y, Tsumune D, Tsubono $\mathrm{T}$ et al (2015) Radiocesium biokinetics in olive flounder inhabiting the Fukushima accident-affected Pacific coastal waters of eastern Japan. J Environ Radioact 147:130-141

24. Sohtome T, Wada T, Mizuno T et al (2014) Radiological impact of TEPCO's Fukushima DaiIchi nuclear power plant accident on invertebrates in the coastal benthic food web. J Environ Radioact 138:106-115

25. Wang C, Baumann Z, Daniel J et al (2016) Contaminated marine sediments as a source of cesium radioisotopes for benthic fauna near Fukushima. Environ Sci Technol 50:10448-10455

26. Otosaka S, Kobayashi T (2013) Sedimentation and remobilization of radiocesium in the coastal area of Ibaraki, $70 \mathrm{~km}$ south of the Fukushima Dai-Ichi nuclear power plant. Environ Monit Assess 185:5419-5433

27. Ono T, Ambe D, Kaeriyama $\mathrm{H}$ et al (2015) Concentration of ${ }^{134} \mathrm{Cs}+{ }^{137} \mathrm{Cs}$ bonded to the organic fraction of sediments offshore Fukushima, Japan. Geochem J 49:219-227

28. Kurita Y, Shigenobu Y, Sakuma T et al (2015) Radiocesium contamination histories of Japanese flounder (Paralichthys olivaceus) after the 2011 Fukushima Nuclear Power Plant accident. In: Nakata K, Sugisaki H (eds) Impact of the Fukushima nuclear accident on fish and fishing grounds. Springer, Tokyo, pp 139-154 
29. Narimatsu Y, Sohtome T, Yamada M et al (2015) Why do the radionuclide concentrations of Pacific cod depend on the body size? In: Nakata K, Sugisaki H (eds) Impact of the Fukushima nuclear accident on fish and fishing grounds. Springer, Tokyo, pp 123-138

30. Shigenobu Y, Fujimoto K, Ambe D et al (2014) Radiocesium contamination of greenlings (Hexagrammos Otakii) off the coast of Fukushima. Sci Rep 4:6851

31. Fujimoto K, Miki S, Kaeriyama $\mathrm{H}$ et al (2015) Use of otolith for detecting strontium- 90 in fish from the harbor of Fukushima Dai-Ichi nuclear power plant. Environ Sci Technol 49:7294-7301

32. Tateda Y, Tsumune D, Misumi K et al (2017) Biokinetics of radiocesium depuration in marine fish inhabiting the vicinity of the Fukushima Dai-ichi Nuclear Power Plant. J Environ Radioact $166: 67-73$

33. TEPCO (2017) Analysis results of fish and shellfish (the ocean area within $20 \mathrm{~km}$ radius of Fukushima Daiichi NPS). http://www.tepco.co.jp/en/nu/fukushima-np/f1/smp/index-e.html. Accessed 26 Mar 2018

34. Buesseler K, Dai M, Aoyama M et al (2017) Fukushima Daiichi-derived radionuclides in the ocean: transport, fate, and impacts. Annu Rev Mar Sci 9:173-203

35. Okamura H, Ikeda S, Morita T et al (2016) Risk assessment of radioisotope contamination for aquatic living resources in and around Japan. Proc Natl Acad Sci U S A 113:3838-3843

36. MHLW (2018) Levels of radioactive contaminants in foods tested in respective prefectures

37. Morita T, Fujimoto K, Kasai $\mathrm{H}$ et al (2010) Temporal variations of ${ }^{90} \mathrm{Sr}$ and ${ }^{137} \mathrm{Cs}$ concentrations and the ${ }^{137} \mathrm{Cs} /{ }^{90} \mathrm{Sr}$ activity ratio in marine brown algae, Undaria pinnatifida and Laminaria longissima, collected in coastal areas of Japan. J Environ Monit 12:1179-1186

38. Bowen VT, Noshkin VE, Livingston HD et al (1980) Fallout radionuclides in the Pacific Ocean: vertical and horizontal distributions, largely from GEOSECS stations. Earth Planet Sci Lett 49:411-434

39. UNSCEAR (United Nations Scientific Committee on the Effects of Atomic Radiation) (2000) Exposure and effects of the Chernobyl accident (annex J). United Nations, New York

40. Miki S, Fujimoto K, Shigenobu Y et al (2017) Concentrations of ${ }^{90} \mathrm{Sr}$ and ${ }^{137} \mathrm{Cs} /{ }^{90} \mathrm{Sr}$ activity ratios in marine fishes after the Fukushima Dai-ichi Nuclear Power Plant accident. Fish Oceanogr 26:221-233

41. Povinec PP, Hirose K, Aoyama M (2012) Radiostrontium in the western North Pacific: characteristics, behavior, and the Fukushima impact. Environ Sci Technol 46:10356-10363

42. IAEA (2004) Sediment distribution coefficients and concentration factors for biota in the marine environment, Technical reports series, vol 422. International Atomic Energy Agency, Vienna

43. Karube Z, Inuzuka Y, Tanaka A et al (2016) Radiostrontium monitoring of bivalves from the Pacific coast of eastern Japan. Environ Sci Pollut Res Int 23:17095-17104

44. Matsuzaki SS, Kumagai NH, Hayashi T (2016) Need for systematic statistical tools for decision-making in radioactively contaminated areas. Environ Sci Technol 50:1075-1076

Open Access This chapter is licensed under the terms of the Creative Commons Attribution 4.0 International License (http://creativecommons.org/licenses/by/4.0/), which permits use, sharing, adaptation, distribution and reproduction in any medium or format, as long as you give appropriate credit to the original author(s) and the source, provide a link to the Creative Commons license and indicate if changes were made.

The images or other third party material in this chapter are included in the chapter's Creative Commons license, unless indicated otherwise in a credit line to the material. If material is not included in the chapter's Creative Commons license and your intended use is not permitted by statutory regulation or exceeds the permitted use, you will need to obtain permission directly from the copyright holder.

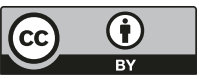

